Scientiæ studia, São Paulo, v. 13, n. 2, p. 3o7-34, 2015

\title{
st \\ Gilbert Simondon e uma filosofia biológica da técnica
}

Wendell Evangelista Soares Lopes

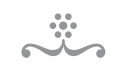

\section{RESUMO}

O presente artigo visa mostrar o significado da filosofia biológica da técnica em Gilbert Simondon. Essa rubrica coloca em ação uma leitura da filosofia da técnica do filósofo francês como uma ontologia regional no interior de sua ontologia geral ontogenética, que, nesse regime específico, baseia-se em um modelo do orgânico. Para tanto, mostraremos que a individuação dos objetos técnicos, sua concretização marcada pela superdeterminação funcional, obriga-nos a pensá-los em sua organicidade e desde uma organologia geral. Ademais, os conceitos de adaptação e de ambiente associado também contribuem enquanto aspectos biológicos que acompanham a concepção de Simondon do modo de existência dos seres técnicos. Como resultado, veremos que quanto mais concreto e adaptado - na série de sua evolução específica -, mais o objeto técnico se aproxima da individualidade propriamente biológica. Essa aproximação não terá, entretanto, o sentido de uma assimilação completa entre o técnico (especialmente, o maquínico) e o orgânico. Na autoprodução vital, permanece sempre um resto para além do maquínico, cuja demonstração é erigida por Simondon, por fim, com a ideia de uma origem vital absoluta dos objetos técnicos enquanto "mutação orientada". Apontaremos que tal origem não tem base meramente humana, mas se estende também para outras esferas do domínio vital.

Patavras-chave • Simondon. Seres vivos. Objetos técnicos. Máquinas. Filosofia da técnica.

\section{INTRODUÇÃO}

\section{Em "Máquina e organismo”, Georges Canguilhem afirma que}

buscou-se quase sempre, a partir da estrutura e do funcionamento da máquina já construída, explicar a estrutura e o funcionamento do organismo; mas se buscou raramente compreender a própria construção da máquina a partir da estrutura e funcionamento do organismo (1952, p. 124).

Nesse mesmo ensaio, o filósofo francês elucida, por fim, algumas iniciativas nessa última direção que ele designava como uma "filosofia biológica da técnica" (Canguilhem, 1952, p. 154), isto é, como uma tentativa de ler as máquinas segundo o mode- 
lo do organismo. É uma das intenções deste artigo mostrar que Gilbert Simondon, que foi aluno de Canguilhem, levou até certo ponto essa tarefa. Mais especialmente, o escopo aqui visado é mostrar como, em sua reflexão, o filósofo pensa o modo de existência dos objetos técnicos a partir do contexto de sua filosofia do vivente. Como pensar a individuação vital em Simondon implica necessariamente contextualizá-la dentro de sua própria reflexão sobre a individuação em geral, da ontogênese enquanto tal, resulta disso que a tese principal, $A$ individuação à luz das noções de forma e de informação (2005a [1958]), e a tese complementar, Do modo de existência dos objetos técnicos (1989 [1958]), devem ser lidas como um argumento contínuo, dentro do contexto de uma ontologia genética geral, a filosofia biológica da técnica aparecendo aí como ontologia regional. Aqui, entretanto, não revisitaremos a ontologia geral simondoniana em sua integridade, mas iremos antes concentrar-nos na elucidação da filosofia biológica da técnica. Nossa estratégia será identificar elementos fundamentais do orgânico que reaparecem como fatores orientadores da análise dos objetos técnicos.

Essa tese tropeça inicialmente com o que defende Michel Tibon-Cornillot, para quem Simondon, embora recuse conceder aos objetos técnicos o estatuto servil de ciências aplicadas, "não buscou ocupar o lugar vazio aberto pela problemática das relações entre os objetos técnicos e os organismos vivos, essa famosa organologia evocada por Canguilhem no início de sua conferência" (2002, p. 167). Não obstante, ao que parece, Tibon-Cornillot compreende mal a própria significação de uma "filosofia biológica da técnica". Para Canguilhem, na história do desenvolvimento dessa "ciência", para além da teoria da projeção, isto é, das tentativas teóricas de Alfred Espinas e Ernst Kapp, um grande passo foi dado com a concepção da técnica como "tática de vida" em Spengler, e com as ideias desenvolvidas por Leroi-Gourhan que, além de corroborar a tese de que a técnica é uma projeção do corpo, aplica também a teoria evolucionista a sua reflexão do progresso técnico. Ora, justamente este passo da filosofia biológica da técnica, na qual se busca uma aproximação sistemática entre biologia e tecnologia, representa a base para uma virada de perspectiva em relação à visão cartesiana de que a invenção técnica é o resultado da mera aplicação de um saber, pois ela aparece antes como uma extensão do fazer biológico enquanto tal. Nesses termos, a perspectiva que afasta a tecnologia da visão usual de ciência aplicada mostra-se não só como uma filosofia da técnica orientada pelo conhecimento biológico, mas também pensa a técnica a partir de sua origem biológica. É porque tem origem vital que ela admite a comparação com o devir vital.

Para a análise da temática de uma filosofia biológica da técnica em Simondon, irei concentrar-me nos três problemas fundamentais da reflexão ontológica simondoniana sobre o modo de existência própria dos objetos técnicos, a saber, (1) o sentido 
do objeto técnico enquanto ser técnico, pensado geneticamente, (2) o que implica pensar também sua evolução e (3) a questão de sua origem absoluta no interior da invenção vital.

\section{A INDIVIDUAÇÃo Dos OBJETOS TÉGNIGOS: CONGRETIZAÇÃo E ORGANIGIDADE}

Devemos começar, então, pelo sentido de um ser técnico enquanto devir individuante. É fácil perceber que na base da reflexão simondoniana sobre os objetos técnicos, tal como desenvolvida em sua tese principal, encontra-se aquilo que ele chama de "método genético". Para responder o que é um objeto técnico é preciso partir das modalidades específicas de sua gênese em contraposição à mera classificação tipológica. A razão para isso é bem simples. Os objetos técnicos não são coisas dadas de uma vez por todas, mas têm uma gênese e sua individualidade modifica-se com essa gênese. A identificação de sua espécie é difícil, e a especificidade que se busca no uso prático não é senão ilusória, pois um uso determinado não se deve à estrutura e ao funcionamento fixos. Segundo Simondon, "a evolução passada de um ser técnico permenece a título essencial nesse ser sob forma de tecnicidade" (Simondon, 1989 [1958], p. 20). Mas como mais exatamente ocorre essa evolução? A resposta de Simondon é clara: "o ser técnico evolui por convergência e por adaptação a si; ele se unifica interiormente segundo um princípio de ressonância interna" (Simondon, 1989 [1958], p. 20). Convergência e adaptação são os nomes que Simondon dá, portanto, para a resolução operada pela evolução do ser técnico. O "problema técnico" (Simondon, 1989 [1958], p. 22), do qual a convergência das funções é a resolução, deve ser buscado na "divergência das direções funcionais" que se encontram "como um resíduo de abstração no objeto técnico" (Simondon, 1989 [1958], p. 23). É, inclusive, a partir da diferença entre divergência e convergência funcionais que o filósofo estabelece a distinção entre objeto técnico abstrato (objeto técnico primitivo) e objeto concreto, sendo este último a versão do objeto técnico liberado progressivamente dos resíduos abstrativos do objeto técnico primitivo. A convergência e a adaptação são justamente formas de redução progressiva desse resíduo.

Com esses primeiros elementos, podemos já pressentir o conceito simondoniano inovador de "concretização", pois ele não significa outra coisa senão a própria individuação técnica, seu modo próprio de existência convergente e adaptativa. Mas dizer apenas isso é muito pouco, se não se explicita o que a concretização representa especificamente enquanto um verdadeiro avanço tecnológico. Um exemplo evocado por Simondon ser-nos-á de ajuda aqui. Refiro-me ao processo concretizante que vai do 
triodo, passando pelo tetrodo, até o pentodo. Um bom referencial para a compreensão desse processo é entender a evolução de seus elementos componentes. No primeiro modelo do triodo, a grade de controle é composta de apenas uma placa e um catodo. Essa formação gerava interfências não esperadas quando da relação das forças no ambiente criado pela própria estruturação do dispositivo. Com a inclusão de uma grade de controle e uma grade de blindagem entre a placa e o catodo, o tetrodo permitiu acabar com as interferências que o modelo anterior possuía, adquirindo assim mais sinergia em seu funcionamento. $\mathrm{O}$ mesmo se pode dizer do pentodo em relação ao triodo, que além dos acréscimos próprios do tetrodo, incluiu também uma grade supressora entre a grade de blindagem e a placa original (ver fig. 1).
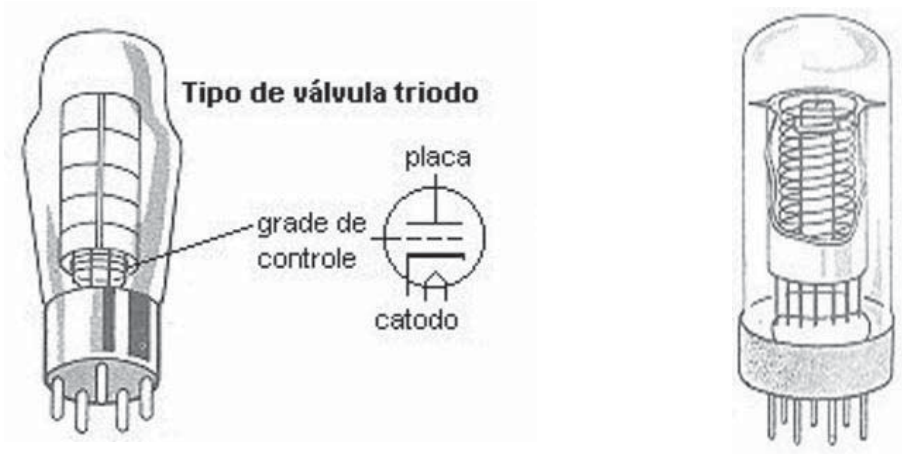

Tipo de válvula tetrodo
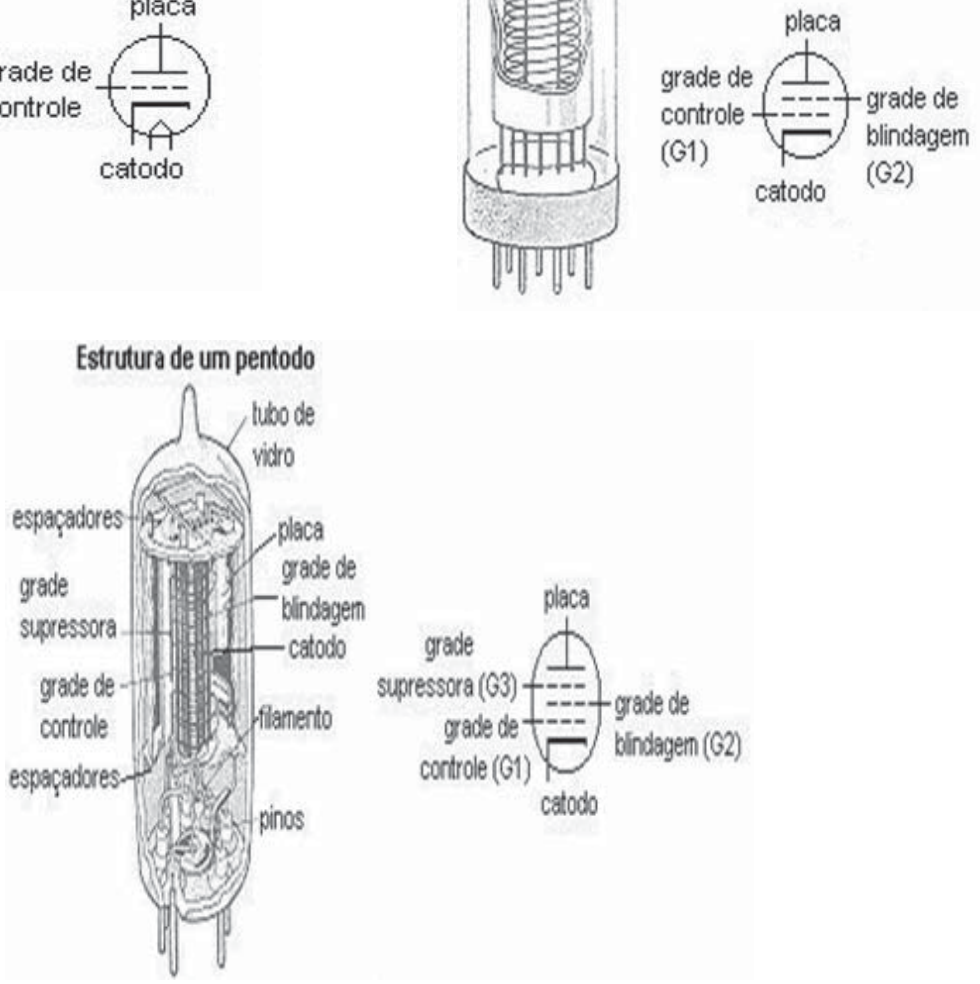

Figura 1. Os três tipos de válvulas referidas (tríodo, tetrodo e pentodo) podem ser observadas com suas respectivas estruturas, o que permite identificar o nível de complexidade estrutural próprio de cada uma delas, fator determinante no resultado sinérgico que possibilita um maior grau de concretização desses objetos técnicos. (Disponível em: 〈http://www. burgoseletronica.net/valvulas_tetrodos.html〉) 
A concretização envolvida nessa passagem envolve certamente uma diferenciação estrutural, mas essa alteração da estrutura não comporta a condição necessária para uma maior concretização; o tetrodo por feixes dirigidos equivale a um pentodo, sendo, inclusive, mais concreto. De qualquer forma, Simondon observa que, apesar da aparente contradição entre a diferenciação estrutural e a concretização, enquanto expressão plurifuncional de um elemento estrutural, essa contradição se desfaz quando se percebe que a ligação entre eles mostra-se justamente no fato de que a diferenciação, tal como a concretização, tem como intenção e permite mesmo suprimir os efeitos secundários que eram antes obstáculos, integrando-os no funcionamento do sistema de causalidades recíprocas, tornando-os, assim, mais sinérgicos. O subconjunto, portanto, é constituído não como uma função única, mas como um grupo sinérgico de funções. É essa sinergia que possibilita a concretização do objeto técnico, pois no objeto técnico concreto cada função substitui e equivale a várias estruturas associadas sinergicamente, enquanto no objeto técnico abstrato, cada estrutura equivale a uma só função. Assim,

o princípio desse progresso é, com efeito, a maneira onde o objeto se causa e se condiciona ele mesmo em seu funcionamento sobre a utilização; o objeto técnico, tema de um trabalho abstrato de organização de subconjuntos, é o teatro de um certo número de relações de causalidade recíproca" (Simondon, 1989 [1958], p. 27).

E mais adiante, "a essência da concretização do objeto técnico é a organização dos subconjuntos funcionais no funcionamento total" (Simondon, 1989 [1958], p. 34).

Para a compreensão da essência da concretização do ser técnico vale a pena ainda atentar para o fato de que termos como "automatismo" e "automação", segundo Simondon, não apreendem bem o significado da essência da individuação técnica, por um motivo simples. Além do sentido industrial e não técnico de tais expressões,

o verdadeiro aperfeiçoamento das máquinas, aquele onde se pode dizer que ele eleva o grau de tecnicidade, corresponde não a um aumento do automatismo, mas, ao contrário, ao fato de que o funcionamento de uma máquina recebe uma certa margem de indeterminação [entenda-se mesmo autonomia] (Simondon, 1989 [1958], p. 11).

Aumento de autonomia ou indeterminação não significa, para Simondon, uma assimilação igualizadora entre os seres técnicos (especialmente, as máquinas) e os seres vivos. Ora, como se sabe, a ideia de um aumento de autonomia das máquinas de infor- 
mação principalmente - característica até então só atribuída aos seres vivos - conduziu principalmente a uma reedição do paradigma cartesiano em biologia. Esse paradigma, a cibernética, pretende-se como "o campo inteiro da teoria de comunicação e controle, seja na máquina ou no animal” (Wiener, 1970, p. 36). ${ }^{1}$ A razão para que o campo se estendesse aos animais devia-se especialmente ao fato de que, com o conceito de máquinas de aprender, os ciberneticistas pensavam lançar luz sobre a "máquina animal" e, portanto, sobre o que Wiener designava já de "cibernética biológica" (Wiener, 1970, p. 17; cf. 1965). É importante salientar que aqui a cibernética torna-se o adversário principal enfrentado por Simondon, pois a completa assimilação entre o orgânico e o maquínico é, a seus olhos, um abuso. A razão do abuso cibernético em Wiener é dupla, e encontra-se na adoção de um método tipológico que pensa os objetos técnicos apenas como classes ou gêneros de seres e também a falsa conclusão da cibernética que opta pela naturalização dos objetos técnicos (cf. Simondon, 1989 [1958], p. 48-9). Essa dupla fraqueza da cibernética irá, inclusive, espelhar-se também duplamente na própria concepção de informação de Simondon como veremos ao final deste artigo.

Distinguindo-se da cibernética, Simondon afirma, então, que é apenas quando se deixa de lado a consideração de uma classe de seres técnicos, para buscar a via que segue as linhas de concretização e sua consequente organização funcional (que realiza sua evolução temporal nos mais diversos graus de automatismo), que "a aproximação entre o ser vivo e o objeto técnico tem uma significação verdadeira, distante de toda mitologia" (Simondon, 1989 [1958], p. 49). E por quê? Porque só assim se pode perceber que um ser técnico não é um objeto natural, mas antes é uma tendência ao ser concreto. É fácil perceber que o objeto técnico abstrato, primitivo, está longe dos objetos naturais, de modo que só à medida que se concretiza sua existência, ele se aproxima sempre mais daquela dos objetos naturais (isto é, espontaneamente produzidos). A assimilação de um ao outro, entretanto, não pode ser completa. Eis o que diz Simondon:

pode-se dizer que apenas os objetos técnicos tendem até a concretização, enquanto que os objetos naturais tais como os seres vivos são concretos desde o início. Não se pode confundir a tendência à concretização com o estatuto de existência inteiramente concreta" (Simondon, 1989 [1958], p. 49).

\footnotetext{
1 Simondon concebe, inclusive, a cibernética como uma nova forma, ao lado do cartesianismo, de conceber a realidade vivente a partir do modelo da técnica: "em duas ocasiões pelo menos, se deixamos de lado a Antiguidade, as técnicas forneceram os esquemas de inteligibilidade dotados de um poder latente de universalidade, sob a forma do mecanicismo cartesiano e da teoria cibernética" (2006 [1958], p. 344).
} 
A concretização tem como expediente, portanto, uma tendência à naturalização do objeto técnico e nada mais. Por outro lado, isso significa também que os objetos técnicos não são só a aplicação de certos conhecimentos científicos, pois "na medida em que existem, eles provam a viabilidade e a estabilidade de uma certa estrutura que tem o mesmo estatuto que uma estrutura natural, ainda que possa ser esquematicamente diferente de todas as estruturas naturais" (Simondon, 1989 [1958], p. 48). O que está em jogo é que o esquema funcional do ser técnico não pode ser deduzido de um único princípio científico, pois seu modo de funcionamento ou de compatibilidade é descoberto empiricamente. Uma vez entendido que o objeto técnico não pode ser deduzido de um único princípio científico e também não é absolutamente concreto, mas apenas tende a uma concretização, pode-se entender que "a concretização dá ao objeto técnico um lugar intermediário entre o objeto natural e a representação científica" ( $\mathrm{Si}$ mondon, 1989 [1958], p. 46). É essa descoberta que torna possível a formação de uma nova ciência, a "tecnologia geral". Nesse sentido, diz Simondon que "todo objeto técnico pode ser científico, e vice-versa" (Simondon, 1989 [1958], p. 246).

Se o objeto técnico e sua ciência, a tecnologia geral, diferem do objeto científico da biologia, isso não quer dizer, entretanto, que esta última não ofereça uma espécie de modelo orientador para a tecnologia geral. Se a simples evocação de expressões, tais como "método genético", "evolução", "resolução de problemas", "saturação", "transdutividade" é bastante sugestiva para o nosso tema, não o é para determinar a aproximação entre a individuação vital e a maquínica, já que em uma ontologia genética como a de Simondon tudo isso se aplica à ontogênese enquanto tal. Ainda assim, não deixa de ser igualmente verdade que, embora a cristalização seja o caso paradigmático de individuação (e isso significa mesmo que o paradigma é extraído do âmbito físico, em contraposição ao paradigma técnico do hilemorfismo), a concretização dos objetos técnicos encontra suas principais analogias não com os objetos naturais de modo geral, mas particularmente com os seres vivos que adquirem proeminência, como a própria noção de "teatro de individuação", um traço vital, aplicado aos seres técnicos já faz pressentir. Simondon, inclusive, ao falar da dimensão histórica do mundo técnico chega a falar de "vida técnica" (cf. 1989 [1958], p. 66-7). Como uma confirmação ainda maior disso, podemos ouvir o que diz Simondon sobre o nível neutro próprio dos seres que se desenvolvem por concretização.

É nesse nível que a comparação entre os seres vivos e os objetos técnicos aparece de forma mais direta ao espírito do observador, encontrando nos dois casos os aspectos da defesa ou proteção (amortização), da atividade (trocas, conversões, motricidade, metabolismo) e de informação (sensorialidade, regulações). Mas a comparação não teria razão, se ela não cobrisse também a relação entre os dife- 
rentes indivíduos ou espécies (resíduo, território) e a organologia interna do indivíduo, em sua autocorrelação por relação a si mesmo (Simondon, 2005b, p. 226).

Não seguirei todos esses casos. Mas abordarei primeiro o que Simondon chama de uma "organologia geral". Dissemos que a essência da concretização era a organização; agora temos que acrescentar que a organização aponta diretamente para o orgânico. Prova disso é a afirmação: "concreto é concretum, quer dizer, qualquer coisa que está aí e na qual, organicamente, algumas das partes não podem ser completamente separadas das outras sem perder seu sentido" (Simondon, 2009 [1968], p. 122). "Organicamente" é na passagem o análogo para convergência, compatibilidade, sinergia, os quais apontam, todos, para a concretização do objeto técnico. Ora, um organismo não é apenas um conjunto de órgãos; do mesmo modo, ao contrário do objeto técnico abstrato que se assemelha mais a um agregado, o objeto técnico concretizado é o análogo do organismo. Ora, um passo mais, e logo se percebe que, embora Simondon distinga entre elemento técnico e conjunto técnico, é ao conjunto técnico que deve ser dada a honra de análogo do organismo, assim como o elemento técnico seria o equivalente do órgão no ser vivo. Nesse sentido, o filósofo não tem a menor dificuldade em dizer que se pode "definir uma organologia geral, estudando os objetos técnicos ao nível do elemento, o que faria parte da tecnologia, com a mecanologia, que estudaria os indivíduos técnicos completos" (Simondon, 1989 [1958], p. 65).

Mas tentando evitar os abusos analógicos ao estilo cibernético, Simondon faz questão de destacar o sentido de tal organologia enquanto puramente funcional e operatória, indicando apenas uma analogia, a saber, “no domínio da vida, o órgão não é separável da espécie; no domínio técnico, o elemento, precisamente porque ele é fabricado, é separável do conjunto que o produziu" (Simondon, 1989 [1958], p. 66-7). A reparabilidade da máquina marca, então, a diferença. Ora, Canguilhem já tinha empregado essa distinção, ao considerar como uma das principais propriedades da máquina sua "normalização", isto é, a "simplificação dos modelos de objetos e das peças de troca, a unificação das características métricas e qualitativas [que] permite a intercambialidade das peças" (Canguilhem, 1952, p. 145). Simondon não parece senão seguir seu antigo mestre ao considerar a previsão de "manutenção" como um dos postulados da mentalidade técnica (cf. Simondon, 2006 [1958], p. 346). Se essa postura parece confirmar o modelo organicista como referencial para a reflexão dos seres técnicos - o que é um dos elementos da "filosofia biológica da técnica" -, não se pode deixar de observar, entretanto, que Canguilhem e Simondon (que escrevem em 1945 e $195^{8}$ respectivamente) insistem sobre um ponto inessencial para a recusa dos abusos comparativos, e expõem-se, por isso, aos sinais de um novo tempo, onde a "protética" 
revela dia após dia quão reparável é o corpo orgânico. É impossível não lembrar que já em 1967 o primeiro transplante de coração foi realizado e revelado ao público, dando daí em diante impulso às novas "próteses", que não pararam mais de aparecer; são próteses de pernas, braços, mãos, exoesqueletos, bexigas com estrutura nano cobertas com células totipotentes, e apetrechos como os olhos biônicos desenvolvidos pela Bionic Vision Australia, que se encontram a ponto de serem implantados no primeiro paciente humano e mesmo ao olho-câmera do cineasta canadense Rob Spence, que se autointitula um eyeborg. Aqui se levanta a questão ao mesmo tempo ontológica e ética da artificialização do orgânico, que deixaremos para tratar mais detidamente ao final deste artigo.

\section{A IndiVIdUAÇÃo DOS OBJETOS TÉGNICOS: GONGRETIZAÇÃ̃o E ADAPTAÇÃo}

Mas esse é apenas um primeiro aspecto do problema, que constitui tão somente o significado do objeto técnico pensado não mais tipologicamente, mas geneticamente. Muito mais se tem a perceber quando entramos no terreno comparativo dos mecanismos evolutivos próprios à bioevolução e à tecnoevolução. Naturalmente, em uma concepção ontogenética como a de Simondon, a própria individuação, isto é, a concretização, pode ser entendida como um primeiro aspecto evolutivo do ser técnico e, nesse sentido, a primeira seção traça esse primeiro aspecto tecnoevolutivo. É por isso que a análise do sentido do objeto técnico confunde-se com aquele de sua própria temporalidade e evolução. Xavier Guchet (2005) mostrou isso em sua análise da evolução técnica que ele chama de a "temporalidade do ser técnico". Como ele diz, "a individuação técnica é o objeto técnico, conhecido segundo seu dinamismo evolutivo" (Guchet, 2005, p. 117). E isso significa, indo além de uma mera história ou sociologia da inovação técnica, que o evolucionismo tecnológico "implica uma revisão maior em nossa concepção do artefato. Este não é um em si indiferente ao tempo" (Guchet, 2005, p. 128). Ao contrário, é possível mesmo falar de um “esquematismo temporal”. Ora, essa situação temporal do existir técnico é marcada pelo seu processo adaptativo, pois, embora não seja algo em si, ou algo dado, ele está em constante embate com seu ambiente, exigindo sempre que seus resíduos abstracionais sejam eliminados. É esse aspecto propriamente evolutivo que precisamos integrar em nossa análise agora.

A primeira coisa de que se deve tomar nota encontra-se no fato de que no processo de concretização, portanto, no processo de organização e autonomização, o objeto técnico expõe-se à possibilidade de uma "hipertelia fatal". Simondon extrai esse termo do campo biológico, e ele significa simplesmente o crescimento exagerado e prejudicial de um órgão; no uso do filósofo, o termo significa, entretanto, uma especi- 
alização exagerada do objeto técnico. Para além do fato menor da utilização de um conceito biológico para pensar o tecnológico, o que está em jogo aqui é a questão da adaptação, elemento, que depois da teoria evolucionista, encerra-se na esfera da vitalidade. Ao tratar desse problema transferido à esfera da tecnicidade, Simondon mostra que os primeiros aviões eram menos superadaptados que os aviões modernos, já que estes últimos precisam de uma pista de pouso muito maior em função de sua grande velocidade. Em um nível muito alto, pensa ele, esta "superadaptação" pode ser comparada ao que acontece, em biologia, com a simbiose e o parasitismo. O exemplo, aqui, é o do planador de transporte, que para voar precisa do auxílio de um rebocador que o coloque em voo; o que é um caso típico de hipertelia. Mas esse é apenas um caso de hipertelia, não o único. ${ }^{2}$ Entretanto, para além dos três casos de hipertelia destacados por Simondon, quero concentrar-me no tipo de adaptação que constitui uma variação do terceiro caso da hipertelia mista, isto é, o caso de uma adaptação não hipertélica. Um dos exemplos dados por Simondon é aquele da turbina de Guimbal. A necessidade de redução de uma turbina e do gerador para equipar uma hidroelétrica levanta a questão da evacuação do calor, pois o gerador muito pequeno explode com o calor. Guimbal pensou em um gerador imenso num poço de óleo e acoplado através de um eixo da turbina, pois, embora a máquina ficasse mais rápida - o que aumenta o calor -, a velocidade, ao agitar o óleo, fazia com que este último evacuasse o calor. Também a água entra aqui com função de resfriamento. Assim, em contraposição a uma adaptação hipertélica, Simondon faz então aparecer uma "adaptação não hipertélica", também designada por ele como "adaptação-concretização", que cria ou condiciona o nascimento de "um ambiente (milieu) ao invés de ser condicionado por um meio misto, técnico e geográfico ao mesmo tempo" (Simondon, 1989 [1958], p. 55). A este terceiro ambiente, misto, exigido e de certo modo condicionado pelo objeto técnico, Simondon dá o nome também de "ambiente associado" (Simondon, 1989 [1958], p. 57). Este fenômeno de autocondicionamento entre ser técnico e ambiente, onde "os dois mundos [geográfico e técnico] agem um sobre o outro” (Simondon, 1989 [1958], p. 53), é o próprio princípio que define a adaptação não hipertélica. E nesse sentido é importante ainda observar que, para o filósofo, nesse processo, "o ato de adaptação [do objeto

\footnotetext{
2 Em carta a Derrida, datada de 3 de julho de 1982, Simondon trata do teor estético presente nos objetos técnicos, e fala, em especial, da monstruosidade própria do Jaguar F. V 12, marcada por seus aspectos poucos funcionais como a forma de sua parte inferior, com nervuras pouco aerodinâmicas, e seu caráter conversível, que expõe o carro a uma turbulência de ar mais elevada. Nesse contexto, diz o filósofo: "também um mutante tem sua própria tecnoestética. Alguns de seus órgãos são hipertélicos, outros hipotélicos e atrofiados. Ele é, de saída, marginalizado pelo seu grupo original, sendo capaz de fundar seu próprio grupo, distinto do grupo de origem e dos outros grupos adjacentes" (Simondon, 1998, 259). É interessante notar que, a esse respeito, Simondon diverge de seu antigo professor, Georges Canguilhem, para quem “a vida tolera monstruosidades. Não há máquina monstro (...). Não há distinção entre o normal e o patológico em física e em mecânica” (Canguilhem, 1952, p. 147).
} 
técnico] não é apenas um ato de adaptação no sentido em que se toma essa palavra quando se define a adaptação em relação a um ambiente que já está dado antes do processo de adaptação" (Simondon, 1989 [1958], p. 55).

Nessa última afirmação pode-se perceber o próprio núcleo da crítica que Simondon dirige contra o "biologismo da adaptação" em sua tese principal. A seguir resumo essa crítica. Antes de tudo, esse biologismo esquece que o crescimento, por exemplo, é individuação e não se encontra ainda na lógica da adaptação. " 3 "A individuação é anterior à adaptação; e não se esgota nela" (Simondon, 1964 [1958], p. 230; 2005a [1958], p. 209). Mas além de fazer da adaptação o aspecto fundamental do ser vivo, esse biologismo configura-se como um "biologismo sem ontogênese". O problema é que ambos, o ambiente e o ser vivo, são pensados como já individuados. A adaptação apareceria, assim, como uma projeção do esquema hilemórfico, aparecendo o ambiente na tradução desse esquema como a parte que dá forma ao ser vivo, a argila vivente tem seu molde mundano. Nada muda, se apenas invertemos a posição de cada uma de suas partes (vivente e ambiente) no esquema e então colocarmos a ênfase no ser vivo como molde do meio, fazendo aparecer com isso a adaptação como influência recíproca. A “zona obscura” da adaptação enquanto ação, isto é, enquanto informação, permanece. Para que se entenda, o que merece ser criticado no biologismo da adaptação não é só a forma como pensa a modalidade da relação entre termos (isto é, a dualidade e disparação indivíduo-ambiente), ${ }^{4}$ mas as condições mesmas dessa relação, isto é, o impensado da dualidade interna ou a disparação no indivíduo. A crítica deve incidir sobre a própria noção de ambiente, que é errônea, pois se mostra como uma "concepção objetiva do ambiente", enquanto não percebe que "não há meio senão para um ser vivo que chega a integrar em unidade de ação os mundos perceptivos" (Simondon, 1964 [1958], p. 236, 2005a [1958], p. 212). Ao não atentar para esse fato, essa concepção objetiva de ambiente falsifica a própria noção de adaptação, que não é outra coisa senão "uma resolução de grau superior que deve engajar o sujeito como portador de uma dimensão nova" (Simondon, 1964 [1958], p. 236, 2005a [1958], p. 212). E disso é preciso que se diga que "a adaptação cria o ambiente e o ser em relação ao ambiente, os caminhos do ser" (Simondon, 1964 [1958], p. 236; 2005a [1958], p. 212).

O resultado é, portanto, o mesmo que o cenário tecnológico já tinha nos apresentado com o autocondicionamento entre o ser técnico e seu ambiente associado, que não é senão condicionado pela adaptação técnica ao mesmo tempo em que a condiciona. Entretanto, uma diferença precisa ser destacada: a evolução técnica fica a cargo da in-

3 Estranhamente, Simondon afirma, entretanto, que o crescimento “pode ser a única [forma de ação amplificadora] possível para certos seres vivos, como os vegetais" (Simondon, 1964. [1958], p. 235, nota 1).

4 "Disparação" é um termo técnico empregado por Simondon para referir à ação que envolve a síntese do que é díspar, quando essa síntese não é mera soma, mas resolução do que é díspar (cf. 2005a [1958], p. 31, 208). 
venção vital. O que está em jogo é o próprio papel ativo do ser vivo na individuação. Antes, porém, precisamos elucidar um novo ponto de aproximação entre o organismo e a máquina, que nos ajudará, inclusive, a entender essa relação.

\section{A Diferença ENTRE o MaQUínico E o ORGÂNico}

Segundo Bernard Stiegler, quanto mais concretizado se torna um objeto técnico - seja em termos de convergência sinérgica seja em termos de adaptação - "mais ele se aproxima da individualidade no sentido fortíssimo que essa palavra tem em biologia" (Stiegler, 1996, p. 174). Precisamos elucidar então até onde vai essa aproximação, pois, como veremos, seu limite marca também a diferença entre o maquínico e o orgânico.

A entrada para essa questão pode ser feita a partir do que vínhamos dizendo sobre a concretização-adaptação, pois o objeto técnico, explicita Simondon, "cria a partir de si mesmo seu ambiente associado e é realmente individualizado nele" (Simondon, 1989 [1958], p. 56) e, ainda,

o princípio de individualização do objeto técnico por causalidade recorrente no ambiente associado permite pensar com mais claridade certos conjuntos técnicos e saber se é preciso tratá-los como indivíduo técnico ou coleção organizada de indivíduos (1989 [1958], p. 61).

Deve-se dar destaque aqui à expressão "individualizado" e "individualização técnica". Em nenhum lugar de seus textos maiores, até onde sei, o filósofo parece fazer uma diferenciação clara entre individuação e individualização, mas é fácil perceber que a expressão "individualização" só é utilizada em sua tese principal depois do tratamento da individuação vital. Além disso, já em 194,0, Raymond Ruyer destacava a indecifrabilidade de certos fenômenos biológicos caso se considere a individualidade como um absoluto, e por isso insistia sobre "o caráter flutuante da individualidade biológica" (Ruyer, 194,0, p. 295). Simondon começa, na parte dedicada à individuação vital, em uma trilha muito próxima a de Ruyer. Simondon observa de saída que a fisiologia levanta o problema dos níveis da individualidade; assim, o embrião não é tão individualizado quanto um ser adulto; mesmo em espécies bem próximas (ou mesmo dentro de uma mesma espécie) pode-se observar essa flutuação entre mais ou menos individualidade, mostrando que as diferenças não se referem necessariamente à organização vital. A organização mostra-se tanto em um único ser, o que é tratado como uma integração interna, bem como na relação entre diferentes seres, o que seria uma integração externa, isto é, onde "o grupo é integrador"; o exemplo inicial é aqui aquele dos cupins. 
Assim, Simondon distingue entre uma "vida pré-individual" como a dos protozoários, uma "zona de transição", onde se encontra uma forma de vida "metaindividual" (por exemplo, os hoje chamados cnidários), e "sistemas totalmente individuados", existindo, inclusive, outros níveis entre esses principais, como o caso dos cupins onde a termiteira pode ser considerada como um superanimal. Não precisamos desenvolver a série de exemplos que Simondon leva a cabo para demonstrá-lo. Aqui, basta-nos perceber como a individualidade do objeto técnico é pensada. No texto "Individuação e invenção", Simondon mostra que a estrutura e o dinamismo enquanto caracteres internos do objeto técnico não podem ser compreendidos "se se confunde objeto técnico e instrumento (outil), o que faz perder sua individualidade própria”, pois os instrumentos - como o telescópio, o alicate, a chave e o martelo - não são dotados de individualidade própria por serem enxertados a outros organismos individualizados com a função de apenas prolongar, reforçar e proteger, mas não de substituir tal organismo, isto é, eles têm um "dinamismo inacabado" (Simondon, 2005a [1958], p. 516). A gradação dos níveis de individualidade sugere que entre a falta de individualidade própria do outil e um objeto técnico totalmente individualizado, há outras expressões de menor e maior individualidade. É o que realmente acontece. Simondon distingue elementos, indivíduos e conjuntos. Assim, um audiômetro, por exemplo, só pode ser considerado um indivíduo caso seja considerado enquanto está em funcionamento, isto é, uma vez associado ao ambiente, em interrelação com a bateria de alimentação, os fones de ouvidos; mesmo o local faz parte do aparelho completo. O audiômetro comprado em loja ("na caixa”, por assim dizer) é, para o filósofo, apenas "um conjunto de formas técnicas que possui uma relativa individualidade" (Simondon, 2005a [1958], p. 516). Aos objetos técnicos sem ambiente associado Simondon confere o nome de "objetos técnicos infraindividuais" (Simondon, 1989 [1958], p. 65). Com toda essa diferenciação, é fácil perceber que a organologia geral não era senão a antecipação de uma gradação da individualidade, pois, em uma colônia, por exemplo, os diversos indivíduos funcionam como órgãos sinérgicos (cf. Simondon, 1964, [1958], p. 157).

Com os motores, por exemplo, tudo se passa de outro modo, pois eles não são só prolongamentos do indivíduo humano, como o é um martelo, e quando em ação também não se pode dizer que são meros elementos, mas conseguem do exterior a energia disponível segundo a necessidade do indivíduo, de modo que ele possui individualidade própria. Simondon vai tão longe com a analogia máquina e organismo, que diz o seguinte:

o escravo é o modelo primeiro de todo motor; ele é um ser que contém nele mesmo sua organização completa, sua autonomia orgânica, mesmo quando sua ação é controlada (asservie) por uma dominação acidental; o animal doméstico é tam- 
bém um organismo. Mesmo através da degradação do estado de domesticidade ou de escravatura, o motor orgânico e vivo conserva de sua espontaneidade natural uma inalienável individualidade. $\mathrm{O}$ escravo cego fugindo ao longo da rota de Larissa é um indivíduo, do mesmo modo que o animal furioso, tornado mais uma vez selvagem e exposto ao perigo de sua vida. A revolta dos animais e dos escravos, malgrado os golpes e a forca, mostra que esses motores orgânicos têm uma autonomia (Simondon, 2005a [1958], p. 516).

Mas Simondon logo se apressa em complementar a observação, e diz que o ser técnico (o motor, em nosso caso) é mais que um instrumento, mas é menos que um escravo, pois sua autonomia é relativa, limitada, sem exterioridade verdadeira em relação ao homem (já que não tem verdadeira interioridade), não tem natureza; "ele pode ser um análogo funcional do indivíduo, mas não é jamais um verdadeiro indivíduo orgânico" (Simondon, 2005a [1958], p. 517). Mesmo que dotada de "mecanismos teleológicos", continua Simondon, a máquina (de calcular, por exemplo) não é um verdadeiro indivíduo, nem tem o mesmo grau de realidade de um escravo, pois sequer pode revoltar-se. Revolta implica "transformação das condutas finalizadas". Com esta última afirmação, deparamo-nos mais uma vez com o problema que anteriormente tínhamos deixado em suspenso, e que agora precisamos atacar mais prontamente, a saber, a questão do verdadeiro lugar da diferença ontológica entre organismo e máquina, onde o peso da balança pende para a autonomia radical do ser vivo enquanto ser da invenção. Para elucidarmos essa diferença, precisamos apenas explicar o que está em jogo na expressão "transformação das condutas finalizadas".

Já tivemos a oportunidade de mostrar que à máquina também foi conferida a faculdade de autoadaptação, de autocondicionamento. Mas isso não significa que a máquina seja capaz, como o homem, do que Simondon chama de "conversão", isto é, da capacidade de "mudar os fins do curso de sua existência" (Simondon, 2005a [1958], p. 517, 559-61). O ponto é que "a máquina não é autocriadora” (2005a [1958], p. 517). E isso pelo simples fato de que, embora a autoadaptação possa evidentemente ser entendida como aprendizagem nas máquinas de informação, não é verdade o que pensa Wiener que, ao tomar o poder de aprender como um dos fenômenos característicos dos sistemas vitais, considera como semelhantes o comportamento do mangusto em esquivar-se dos sucessivos botes da naja e a atividade das máquinas de aprender, particularmente das máquinas enxadrísticas, já que ambas as atividades encerram “o mesmo elemento de aprendizado em termos de experiência dos hábitos do adversário, bem como dos próprios [hábitos]" (Wiener, 1970, p. 218). A desrazão dessa abusiva assimilação de Wiener é dupla. Ela se evidencia tanto no que se refere à natureza da informação, como no silêncio sobre a origem da informação. 
Quanto à natureza da informação, deve-se entender, primeiro, que o conceito de informação de Wiener é resumido por Simondon como sendo "aquilo que se opõe à degradação da energia, ao aumento da entropia: ela é essencialmente neguentrópica" (Simondon, 2005a [1958], p. 220). Para Simondon, essa resposta não é suficiente, pois uma fita magnética ou uma película fotográfica registram sinais, mas não verdadeiras informações. Além disso, "informação é aquilo que implica regularidade e retorno periódico, previsibilidade" (Simondon, 2005a [1958], p. 220). Aqui, o sinal não é só emitido e transmitido pela modulação de uma energia, mas é recebido por um dispositivo com funcionamento próprio, isto é, o sinal é o que deve ser recebido e ganha significação. Só há informação quando o emissor e o receptor formam um sistema. A informação "é uma maneira de ser do sistema supondo potencialidade e heterogeneidade" (Simondon, 2005a [1958], p. 195, nota 2), que se distingue daquilo que Simondon chama de meros "sinais de informação", os quais seriam instrumentos não necessários dentro de um sistema, podendo ser centrípetos (como os que se oferecem aos órgãos do sentido) ou centrífugos (como os que ativam uma reação, um gesto etc.).

Ora, é exatamente por seguir o biologismo da adaptação que a cibernética acaba por repetir o esquema hilemórfico que é próprio daquele (cf. Wiener, 1970, p. 211). Desse modo, ela deixa intocada a "zona obscura" do que, para evocar a tese de Ruyer, seria a origem da informação, que na máquina mostra-se como um nó fatal. Ruyer já destacara que “aprender não consiste em comportar-se, mesmo com certa flexibilidade, segundo um feedback previamente montado. Aprender é, essencialmente, montar um novofeedback" (Ruyer, 1972 [1954], p. 57). Simondon parece seguir a pista de Ruyer. Ele também distingue entre a adaptação própria da máquina como adestramento (dressage), e a adptação vital como aprendizagem. Diferentemente do estereótipo da conduta e do estreitamento da relação com o meio que encontramos na máquina adestrada, a aprendizagem vital

é a aprendizagem que aumenta, ao contrário, a disponibilidade de ser em relação aos diferentes ambientes nos quais se encontra, desenvolvendo a riqueza do sistema de símbolos e de dinamismos que integram a experiência passada segundo um determinismo divergente. Nesse segundo caso, aumenta a quantidade de informação caracterizando a estrutura e a reserva de esquemas contida no ser; os saltos bruscos sucessivos que podem ser nomeados conversões marcam os momentos em que a quantidade de informações não integradas tornouse muito grande, o ser unifica-se mudando de estrutura interna para adotar uma nova estrutura que integra a informação acumulada (Simondon, 2005a [1958], p. 517). 
Essa descontinuidade não se encontra no autômato, já que ele não muda de estrutura. Nele, há incorporação da informação e não incompatibilidade entre a estrutura e a informação adquirida, pois a estrutura determina a própria forma de aquisição da informação. Por isso, não é difícil entender a crítica esboçada por Simondon na Introdução de sua tese principal à cibernética da vida.

\begin{abstract}
(...) o vivente não pode ser reduzido a um autômato que mantém um certo número de equilíbrios ou que busca compatibilidades entre várias exigências, segundo uma fórmula de equilíbrio complexo composto de equilíbrios mais simples; o vivente é também o ser que resulta de uma individuação inicial e que amplifica essa individuação, o que não faz o objeto técnico ao qual o mecanismo cibernético queria reduzi-lo funcionalmente. Há no vivente uma individuação pelo indivíduo e não só um funcionamento resultante de uma individuação uma vez realizada, comparável a uma fabricação; o vivente resolve problemas, não só se adaptando, quer dizer, modificando sua relação com o ambiente (como pode fazer uma máquina), mas modificando a si mesmo, inventando estruturas internas novas, introduzindo-se ele mesmo completamente na axiomática dos problemas vitais (Simondon, 1964 [1958], p. 9; 2005a [1958], p. 27-8).
\end{abstract}

Ao introduzir-se na axiomática dos problemas vitais, "o vivente tem efeito (fait oeuvre) informacional, tornando-se ele mesmo um nexo de comunicação interativa entre uma ordem de realidade superior a sua dimensão e uma ordem inferior a ele, que o organiza" (Simondon, 1964 [1958], p. 17, nota 1, 2005a [1958], p. 28, nota 4). Barthélémy (2005) lembra que Canguilhem observa a novidade dos trabalhos de Ruyer e Simondon, por conseguirem pensar a informação como "informação informante" e não mais meramente como "informação informada". Em uma expressão "ligada diretamente ao processo de neotenisação, a individuação é a raiz da evolução" (Simondon, 1964 [1958], p. 239, nota 1; 2005a [1958], p. 214, nota 24). Por fim, vê-se que é o lugar do indivíduo na condução da própria individualização, isto é, o papel ativo do ser vivo no processo informacional, que aparece como ponto de diferença crucial entre a máquina e o organismo.

Aqui, entretanto, antes de passarmos para o último ponto deste artigo, convém saber o que exatamente significa esse papel ativo do organismo. Alberto Toscano, por exemplo, alinha o pensamento de Simondon ao interacionismo, entre o determinismo e o organicismo. A interação depende da própria disparação que o organismo carrega consigo, sua individuação interna, perceptiva, por exemplo. Mas Toscano especifica que não se trata de pensar o organismo como o agente, mas como "resolução local de disparação, como a invenção de uma compatibilidade entre domínios e demandas he- 
terogêneos" (Tosacano, 2006, p. 149). O organismo, não o gene, é a entidade privilegiada, não porque serve de princípio, mas porque ele é “o teatro da individuação", o que quer dizer que "o organismo não é um sujeito de decisão, mas a invenção não intencional de uma resolução local de disparação e metaestabilidade" (Toscano, 2006, p. 150). A meu ver, Toscano acerta em quase tudo, tanto ao não alinhar o pensamento de Simondon ao mecanicismo cibernético ou diretamente ao organicismo como também ao destacar o não privilégio do gene, mas erra, entretanto, ao negar ao vivente o papel de agente. Pois que o ser vivo seja o "teatro da individuação" não significa que ele é um recinto onde se passam coisas, mas significa que nele a individuação acontece de dentro para fora. Ora, a metáfora do teatro também se aplica aos objetos técnicos, como vimos, mas a diferença é que seu autocondicionamento não é do mesmo tipo que o do ser vivo, justamente porque é o vivente que mantém sua própria individualização dando vida à própria máquina. Que o indivíduo vital é agente pode-se facilmente demonstrar. Inicialmente, porque o organismo possui um papel no processo adaptativo, que é visto como uma ontogênese permanente. Além disso, Simondon ainda diz claramente que "viver consiste em ser agente, ambiente e elemento de individuação" (Simondon, 1964 [1958], p. 239, 2005a [1958], p. 214). Ademais, no organismo tudo coopera para a vida e não apenas certas estruturas ou a mera soma delas. A matéria viva não é um conjunto de órgãos, mas é seu fundo, aquilo que liga os órgãos; ela também não é indeterminação, passividade, algo como uma aspiração cega (cf. Simondon, 1989 [1958], p. 6o).

Simondon apresenta então um resumo dos pontos principais de sua diferenciação entre o organismo e a máquina.

As "máquinas reflexas" da cibernética são essencialmente conjuntos de reguladores que simulam bem os tactismos (com seus limiares e suas inversões de sentido, as tartarugas de Grey Walter), assim como os condicionamentos pavlovianos. O homeostato de Ashby simula bem a pesquisa de equilíbrios complexos entre o indivíduo e o meio. Quanto às memórias das máquinas de informação, elas simulam antes de tudo a memória imediata. Não obstante, são os processos de desenvolvimento (incluindo a reprodução amplificadora e diversificadora), os aspectos afetivo-emotivos da vida e os atos de invenção individual, que aparecem como o aspecto mais distante, nos seres vivos, da existência das máquinas. Isso que é o mais distante do objeto técnico é a consciência e tudo o que ela recobre (Simondon, 2005b, p. 165).5

5 Como se pode notar, Simondon elenca o desenvolvimento - e a reprodução como parte dele - entre os pontos de dissemelhança entre o orgânico e o maquínico. Tanto em sua tese principal como na tese complementar, isso se 


\section{A INVENÇÃO VITAL OU DA ORIGEM DOS OBJETOS TÉGNIGOS GOMO "MUTAÇÃO ORIENTADA"}

Depois de tudo que vimos, parece bastante plausível a hipótese de uma filosofia biológica da técnica em Simondon. Também defenderam teses parecidas, embora em outros termos, Schmidgen (2005) e Guchet (2008). O resultado particularmente destacado aqui é que a aproximação entre o vivente e a máquina, embora possuindo vários pontos de contato como a organologia, a teoria da adaptação e da individualização progressiva, não pode, entretanto, ser excessiva como o é na teoria cibernética, que parte de uma concepção tipológica e mecanicista, tentando assimilar completamente o orgânico e o maquínico. O que não é percebido na cibernética é a invenção internamente atuada - ou se se preferir o caráter de "informação informante" - como traço essencial da vida, que demarca a diferença entre o absolutamente natural (o vivo) e aquilo que tende à naturalização (o técnico). Portanto, a filosofia biológica da técnica que se pode pensar junto com Simondon não pretende tornar equivalentes o organismo e a máquina. Como resultado pode-se também pensar que do mesmo modo que a leitura do orgânico desde o paradigma da máquina não podia ser totalizante, também a leitura da máquina a partir do modelo orgânico não pode ser total, já que os objetos técnicos não podem ser identificados aos seres vivos, aos objetos naturais. Mas mesmo onde Simondon vê divergências, é possível, a partir das novas conquistas tecnológicas (mas não só), encontrar aproximações. Enquanto conceito que demarca a individuação técnica, o termo concretização abrange todos esses aspectos de maneira extremamente dinâmica, pois demarca o caráter de devir do objeto técnico, o que lhe concede o status de algo mais do que uma mera matéria morta, mas, ao mesmo tempo, enfatiza essa tendência para o concreto como um ainda-não-ser-concreto, algo que todo ente natural (vivo) é.

Duas observações mais gerais precisam ser tiradas desse resultado. Antes de tudo, ele nos informa que embora Simondon tenha considerado aquela que seria apenas uma primeira geração da teoria cibernética, nada muda com a chegada das novas gerações de máquinas cibernéticas, que foram desenvolvidas nos últimos anos. ${ }^{6}$ Isso já está dado

evidencia quando ele diz, por exemplo, que "a mais eminente transdução biológica é, portanto, essencialmente o fato de que cada indivíduo reproduz análogos” (Simondon, 1964 [1958], p. 145; cf. 2005a [1958], p. 70-1). Aqui, entretanto, deixamos esse argumento de lado porque a determinação da reprodução - e também do desenvolvimento - como essencialidade do vivente é ainda matéria de controvérsia e expõe-se a novas comparações que enturvam tal diferença. Bons exemplos podem ser extraídos do grande Samuel Butler (cf. 1914, p. 184); Deleuze e Guattari (1976 [1972], p. 361), mas também em pensadores mais contemporâneos.

6 Mesmo Norbert Wiener observou que a famigerada presunção humana de que as máquinas não podem possuir nenhum grau de originalidade, isto é, que delas nada pode sair que não lhe tenha sido inculcado, deve ser rechaçada, mas não porque as máquinas podem exibir mais do que lhe foi inculcado, e sim porque "ainda quando as máquinas 
pelo próprio conceito de concretização como tendência, isto é, enquanto indicando um ainda-não-ser-concreto. Bem entendido, tal conceito não é senão a versão simondoniana do conceito de cultura, entendida agora a partir de uma ontologia ontogenética, isto é, a partir de sua individuação. Só para que se entenda, em seu estudo crítico sobre os limites do progresso humano - em resposta direta a Ruyer (1958) - Simondon alinha ao lado da técnica outros dois domínios de concretização, a saber, a linguagem e a religião. Assim,

não só existe uma série sucessiva de domínios de desenvolvimento das concretizações objetivas, linguagem, religião, técnica, mas existe também entre esses domínios, sobreposições duráveis [a Reforma Protestante enquanto progresso da linguagem no devir religioso], manifestando uma busca de universalidade" (Simondon, 1959, p. 371).

Como um segundo ponto complementar ao primeiro, e que é o que nos interessa especificamente para nosso ponto final, aparece o problema da dualidade entre o natural e o artificial, ou entre a natureza e a cultura, por assim dizer. O que está em jogo aqui é o fato de a origem biológica dos objetos técnicos ser o lugar último em que se apoia uma filosofia biológica da técnica. Antes de tudo, diz Simondon:

não é suficiente dizer que o objeto técnico é isso onde há a gênese específica procedente do abstrato ao concreto; é necessário ainda precisar que essa gênese realiza-se por aperfeiçoamentos essenciais, descontínuos, que fazem com que o esquema interno do objeto técnico se modifique por saltos e não segundo uma linha contínua (Simondon, 1989 [1958], p. 38).

Isso não quer dizer que esse aperfeiçoamento descontínuo seja casual, uma mera mutação; muito pelo contrário, são os aperfeiçoamentos contínuos e menores que se dão de maneira casual e mutante, por assim dizer. Os aperfeiçoamentos maiores são antes uma "mutação orientada" (Simondon, 1989 [1958], p. 38). A verdadeira invenção evolutiva, enquanto concede origem absoluta aos objetos técnicos, se dá por saltos, pois é fruto ou depende de pensamento capaz de previsão e imaginação criadora. A invenção é criadora, seguindo assim o próprio caráter autopoiético do vivente. Por esse motivo,

não superam de modo algum a inteligência do homem, bem podem, e logo conseguem" transcender algumas das limitações de seus projetistas, podendo, inclusive, "ser simultaneamente efetivas e perigosas", na medida em que certas capacidades não previstas na programação podem aparecer (cf. Wiener, 1974, p. 12). Mesmo os atuais robôs cientistas de que nos fala King (2011) não podem levar a frente hipóteses, experimentos e mesmo descobertas sem a programação anterior de cientistas humanos. 
só raramente a invenção é obra do acaso. A unidade do futuro ambiente associado é representada pela relação do organismo com seu ambiente. E a respeito disso, é preciso ter em mente que "sem a finalidade pensada e realizada pelo vivente, a causalidade física não poderia sozinha produzir uma concretização positiva e eficaz" (Simondon, 1989 [1958], p. 49). Ou, de outro modo, "o objeto técnico individualizado é um objeto que foi inventado, quer dizer, produzido por um jogo de causalidade recorrente entre a vida e o pensamento no homem" (Simondon, 1989 [1958], p. 60). Ou, como diz John Hart, "o objeto técnico individualizado corresponde diretamente à dimensão humana” (Hart, 1989, p. xI).

Essa origem absoluta dos objetos técnicos, que segue os caminhos do pensamento imaginativo do vivente humano, mostra-se não só no ato da invenção como tal, mas também naquele da regulagem. Isso pode ser claramente entendido com a diferença entre operador e regulador:

em um grande número de fábricas modernas a função de regulador é estritamente distinta daquela de utilizador da máquina, quer dizer, do operador [ouvrier], e é interdito aos operadores regular eles mesmos sua própria máquina. Ora, a atividade de regulagem é aquela que prolonga de maneira mais natural a função da invenção e da construção: a regulagem é uma invenção perpetuada, ainda que de algum modo limitada. A máquina, com efeito, não é descartada de uma vez por todas na existência a partir de sua construção, sem necessidade de retoques, de reparações, de regulagens (Simondon, 1989 [1958], p. 150).

Portanto, a origem e a evolução dos objetos técnicos dependem daquele que inventa e opera de forma reguladora o existir do objeto técnico. Uma vez que se entende que as criações e evoluções técnicas têm atrás de si a intervenção do vivente humano (mas não só humano, como veremos), uma conclusão simples aparece inevitavelmente. O devir mutante dos objetos técnicos não é cego, sem sujeito. Como bem explicitou também Guchet, contra essa falácia que constitui um dos elementos do "evolucionismo tecnológico", "a inovação técnica só é suscetível se justamente for despojada de seu próprio tempo, para ser inscrita no tempo orientado da evolução" (2005, p. 301).

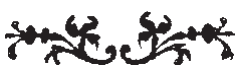




\section{Considerações finais}

Depois de tudo o que dissemos e desse resultado, estamos certamente prontos para tecer algumas observações finais sobre as questões com as quais a filosofia biológica da técnica em Simondon se depara. Sem a pretensão de respondê-las de maneira definitiva, gostaria de pelo menos deixar indicado direções possíveis para um possível tratamento.

A primeira questão refere-se a uma suposta tensão no pensamento de Simondon no que diz respeito à autonomia do objeto técnico, sua trajetória evolutiva e seu papel transdutivo na relação entre o homem e a natureza. Para Andrés Vaccari, "por um lado, Simondon concebe a máquina como um sistema autônomo que evolui de acordo com sua lógica interna. Por outro lado, a técnica deve ser considerada no contexto humano e natural" (2010, p. 163). Ou seja, a tensão é aquela que enfatiza, por um lado, a autonomia do objeto técnico e, por outro, seu caráter meramente mediativo. Diferentemente de Vaccari, entretanto, é necessário dizer duas coisas. De um lado, ele exagera o sentido da autonomia dos objetos técnicos. Pois, como vimos, a individualidade do ser técnico não pode ser assimilada completamente àquela do vivente. De qualquer modo, isso não significa que seu processo individuante seja um mero joguete nas mãos de indivíduos humanos, pois os objetos técnicos, de fato, contêm em si a lógica, por assim dizer, de seu próprio devir. Isso, entretanto, só é possível, porque o artefato humano carrega, no caso da invenção humana, a finalidade constituinte de seu próprio ser para além do seu caráter abstrativo. Em outros termos, a trajetória inerente do ser técnico é um reflexo do próprio resíduo abstracional de sua própria concepção original. Por isso, o ser técnico contém em si mesmo potencialmente seu aperfeiçoamento, pois a intenção, que se organiza e se estabiliza nele, preexistia de maneira real, ainda que confusa, naquele protótipo a partir do qual um novo artefato receberá o aperfeiçoamento. É por isso também que o último produto de uma evolução técnica não pode ser tomado como objeto concreto, pois sempre permanece alguma abstração residual que confere à evolução do ser técnico o caráter de tendência. Portanto, prestar a devida atenção a uma não concretização total do objeto técnico é perceber que sua evolução está estritamente atrelada à finalidade pensada e realizada pelo ser vivo (humano).

Uma segunda questão que se abre com a determinação do objeto técnico enquanto pertencente à ordem do artificial é aquela que acusa a distinção entre o natural e o artificial como pertecendo a uma metafísica tradicional ultrapassada. Essa acusação está baseada na ideia de uma tecnogênese vital e humana. A questão é, em outros termos, aquela concernente à própria origem da técnica, e pode ser enunciada assim: a técnica é produzida pelo homem, ou o produz, ou mesmo ambas as coisas? Vaccari, por exemplo, afirma que Simondon "encara o ser vivo e o artefato como o resultado de 
ontogêneses heterogêneas, o que impede, desde o começo, considerar a gênese conjunta do humano-técnico e do vivente-técnico" (Vaccari, 2010, p. 163). Deixo de lado as razões que Vaccari utiliza para fundamentar esse ponto, já que parece reclamar a emergência de um lamarckismo ingênuo insustentável no interior da reflexão sobre a técnica. ${ }^{7}$ Muito mais merecedor de nossa atenção aqui é aquele "lamarckismo de segundo grau" defendido por Bernard Stiegler (1996). Também ele reprovou em Simondon o fato de ter ignorado o papel da técnica na constituição dos seres vivos. Stiegler lembra que Simondon teve o mérito de introduzir a metaestabilidade no interior da individuação dos objetos técnicos. Estes sempre tinham sido considerados como matéria morta estável em oposição à matéria viva metaestável. A partir disso, ele extrai uma consequência que hoje parece crescer no meio filosófico, a saber, a defesa de uma crescente mistura entre o vivo e o não vivo, entre o natural e o artificial. Para Stiegler essa mistura "atinge hoje um ponto de ruptura, no sentido em que faz explodir a própria ontologia do vivo" (Stiegler, 1996, p. 175), pois, segundo ele, a ideia de que há uma essência do vivente, algo que de qualquer modo jamais podemos chegar a determinar, torna-se questionável com a chegada das técnicas de manipulação genética. Embora resultado de desenvolvimentos da biologia molecular, elas têm, entretanto, a consequência paradoxal de "explodir as próprias bases da biologia molecular" (Stiegler, 1996, p. 175). Ele salienta que François Jacob defende a verdade do darwinismo contra o lamarckismo, segundo a qual o programa genético "não recebe lições da experiência”, de modo que a biologia parece confirmar a não existência da "hereditariedade dos caracteres adquiridos", já que não há comunicação entre a memória da espécie (genoma) e a memória individual (nervosa). Contra esse corolário da ciência biológicomolecular, entretanto, Stiegler defende que a tecnologia biológico-molecular, ao contrário, introduz um "lamarckismo de segundo grau", uma vez que a técnica de manipulação genética permite justamente aquela comunicação outrora impedida. A memória nervosa do geneticista "entra na memória da espécie" e transgride o interdito da incomunicabilidade entre essas duas memórias. Isso permite imaginar, inclusive, "a transformação do homem em seus caracteres biológicos" (Stiegler, 1996, p. 176).

A tese de Stiegler não é, certamente, desprovida de razão. Além disso, pode-se dizer que a renovação do lamarckismo não vem apenas do lado da técnica, mas pode ser pensada também desde a ciência biológica, pois, como destacou a microbiologista Lynn

7 Vaccari pensa, por exemplo, que "a fabricação e o uso de ferramentas teve um papel central na diferenciação dos hemisférios cerebrais (Ambrose, 2001), no desenvolvimento do pensamento causal (Wolpert, 2003) e na evolução da linguagem (Corballis, 1999). Tudo isso problematizou profundamente a divisão metafísica entre a natureza e a cultura" (Vaccari, 2010, p. 155). Mas note-se que o que dizem Ambrose (2001) e Wolpert (2003) é exatamente o oposto do que afirma Vaccari. Mesmo que este não seja o caso para Corballis (1999), as duas primeiras inversões falaciosas já põem em xeque o argumento de Vaccari. 
Margulis: "a simbiose é uma classe de lamarckianismo" (Margulis, 2002, p. 19). Em Lamarck, a herança de caracteres adquiridos era concebida como resultado de circunstâncias ambientais; na endossimbiose, o indivíduo herda não um caractere novo, mas um organismo novo (com seu genoma). Trata-se, portanto, de um neolamarckianismo. "A simbiogênese é a mudança evolutiva segundo a herança de conjuntos de genes adquiridos" (Margulis, 2002, p. 19; cf. Margulis \& Sagan, 2003, p. 53-5). E é bastante óbvio que a mesma lógica deve ser aplicada ao caso da transferência lateral de genes, que é a base das técnicas de manipulação genética. Ernst Mayr, entretanto, critica a aproximação da simbiogênese com o "princípio de herança dos caracteres adquiridos" (Lamark), pois, segundo ele, "a herança lamarquiana consiste na transmissão de fenótipos modificados, enquanto a simbiogênese implica a transferência de partes de genomas incorporados" (Mayr, 2003, p. 15-6). De qualquer forma, o que tanto Stiegler e Margulis reclamam não é um simples lamarckismo e, nesse sentido, não creio que a rubrica de um neolamarckismo esteja completamente desautorizada. Mais importante para nós aqui é atentar para o fato de que a ênfase de Stiegler no aspecto técnico da revolução neolamarckista é exagerado, pois é completamente dependente da própria tarefa vital como tal. É a vida dos micro-organismos que nos ofereceu uma nova imagem das próprias possibilidades vitais. Hans Jonas, especialmente, mostrou que a suposta explosão ontológica de que fala Stiegler é desmedida. Ele destaca que, embora exista analogia, uma diferença permanece entre a engenharia convencional e a "engenharia biológica”, especificamente no caso da manipulação genética, em função das próprias condições subjacentes a esta última, a saber,

sua própria realidade e morfologia já sempre completa - os organismos como tais - são o dado primário; (...) [o “aperfeiçoamento" inventivo] está ligado ao espaço de jogo de um sistema já altamente determinado com funções internas de troca, sob a condição de que se mantenham as capacidades vitais. Assim, temos uma "fabricação" parcial (e muito marginal), ao invés de total, uma alteração do plano antes que o planejamento de novo, e o resultado não é um artefato apenas em uma pequena fração de sua composição, já que no principal continua sendo ainda uma criação original da natureza (Jonas, 1987, p. 165).

Portanto, utilizar os objetos técnicos para orientar e colocar em ação o processo natural não significa dizer que o resultado é um artefato, simplesmente "não se pode falar de seres vivos 'artificiais"” (Jonas, 1987, p. 201, nota 1); nem muito menos se pode dizer que a "construção" seja totalmente técnica, e, por isso, seria melhor chamá-la de “reprojetamento". A esse respeito Simondon está do lado de Jonas, e ele próprio já tinha algo a acrescentar de maneira muito pontual: 
a artificialidade essencial de um objeto reside no fato de que o homem deve intervir para manter esse objeto em existência ao protegê-lo contra o mundo natural, dando-lhe um estatuto separado de existência. A artificialidade não é uma característica denotando a origem fabricada do objeto por oposição à espontaneidade produtora da natureza. A artificialidade é isso que é interior à ação artificializante do homem, quer essa ação intervenha sobre um objeto natural ou sobre um objeto inteiramente fabricado (Simondon, 1989 [1958], p. 46-7).

Eis o que, para traduzir, as palavras de Simondon acrescentam para o problema: o fato de os novos organismos formados a partir de tais técnicas serem literalmente autônomos. É exatamente essa autonomia, que independe da necessidade de novas intervenções humanas para sua continuação, o que impede que o resultado seja tratado como "produto" ou artefato. Nada na manipulação genética coloca, portanto, em questão a separação ontológica entre o que é vivo e o que é artificial. Aí há que se entender que são coisas distintas o aproveitamento da técnica vital para a formação da própria vida e a invenção da vida pela técnica. Além disso, cabe salientar também que a consideração de Stiegler, segundo a qual a manipulação genética por si só altera a essência de um ente específico, acaba por tornar-se refém de uma concepção substancialista de essência. Pois se pode dizer, por acaso, que um ser vivo geneticamente manipulado foi alterado em sua essência por simplesmente brilhar no escuro? A simples pergunta é o suficiente.

Finalmente, podemos passar a uma última questão: aquela relacionada ao problema da biotécnica. Vaccari enumera quatro diferentes vias que recaem sob esse domínio:

(1) a problemática da zootécnica, cuja assombrosa sofisticação e complexidade só recentemente foi descoberta; (2) a engenharia de nichos (niche engineering), quer dizer, a maneira pela qual grupos animais modificam seus habitats, criando pressões seletivas que afetam as condições evolutivas das gerações seguintes; (3) a engenharia epistêmica ou a modificação por parte dos seres viventes das propriedades informacionais e epistêmicas de seu entorno; e (4) a biossemiótica ou o fenômeno da significação e a comunicação em e não só entre os seres vivos (Vaccari, 2010, p. 164).

Em todos esses pontos está a ideia, certamente de grande valor, de que a técnica não é algo que se agrega a um ser vivo pré-existente; antes, é preciso dizer que o organismo já é técnico, uma vez que ele é "um ente cuja propriedade é a capacidade de organizar autonomamente seu exterior, estabelecendo relações nas quais certos aspectos tomam um aspecto instrumental em função dessas relações" (Vaccari, 2010, p. 164). 
Isso levanta um grande problema que é em parte respondido por Simondon, e em parte cria aporias para o filósofo francês.

Antes de tudo, é preciso observar que, para Simondon, a técnica não é só um mero prolongamento dos órgãos, mas é sobretudo uma invenção biológica. Logo de início, Simondon afirma que "as técnicas não são apenas humanas; elas são também um certo aspecto da atividade dos animais; a atividade técnica é uma maneira de constituir a organização a partir de uma atividade orientada dos seres organizados" ( $\mathrm{Si}$ mondon, 2005b, p. 225). De maneira mais específica, o filósofo estabelece a diferença entre mediação instrumental simples e complexa. A primeira refere-se à manipulação ou ao uso de instrumentos como mediadores para a resolução de problemas que o animal encontra em seu agir finalizado. Desse tipo de recurso na ação valem-se até mesmo os artrópodes, dos quais Simondon destaca em especial a vespa (Ammophila urnaria), que utiliza um seixo acima de seu ninho, e certas formigas (Oecophylia smaragdina e Oecophylia longinoda) que fabricam ninhos com folhas, que são depois "costuradas" pela larva. Até o século XIX, considerava-se tais atividades, nos insetos, como comportamentos hereditários, regidos por leis fixas e instintivas. Mas Simondon acredita que "atualmente, ainda que a capacidade de resolver problemas seja mais geralmente encontrada nos vertebrados, nada permite excluir a priori atos de invenção nos artrópodes" (Simondon, 2005b, p. 3०9). A grande diferença dos artrópodes para outros vertebrados é a forte presença de sociedades, o que sugere um determinismo bem mais rigoroso na conduta dos mesmos, se se considera que a mediação instrumental ou qualquer outro ato de invenção exige condições individuais de gênese. Enfim, não se pode dizer que os artrópodes são incapazes de mediação instrumental, antes se deve falar apenas em um sistema de ação menos adequado à atividade inventiva. A mediação instrumental complexa, onde o problema da mediação concerne não só ao uso, mas também à preparação, é algo que não se pode ampliar tão extensivamente. De qualquer modo, está claro que a invenção biológica estende-se escala vital abaixo para muito aquém do humano.

Não obstante, fica claro também que não se pode falar de maneira muito geral aqui em biotécnica, caso isso signifique que o fazer técnico é próprio do ser orgânico enquanto tal; o que se depreende da maneira como o próprio Simondon parece estabelecer uma relação entre a invenção, a artificialidade e a orientação orgânica, que no caso dos artrópodes é apenas fragilmente concedida.

Isso pode parecer a princípio uma fraqueza, mas há também que se perguntar se uma tal extensão não acaba por tornar por demais elástico o próprio conceito de técnica, a ponto de termos de concebê-lo mais ao estilo de Spengler, isto é, como "tática de vida”, justamente uma ampliação que Simondon evita desde o título de sua obra, que se pretende uma investigação sobre o modo de existência dos objetos técnicos. A con- 
centração sobre o objeto técnico, ao que parece, afasta, para Simondon, de saída, qualquer possibilidade de pensar a técnica em sentido tão amplo. Pois deve-se perguntar: é possível conceber a concretização como essência da técnica em um sentido tão amplo como aquele de uma tática de vida? De qualquer modo, fica em aberto também decidir se aqui não nos encontramos diante de uma aporia própria à questão da essência da técnica enquanto tal, e não apenas da filosofia biológica da técnica particularmente em Simondon. Certamente tais problemas não apagam de modo algum o valor da reflexão simondoniana sobre a técnica, que, como qualquer "ciência" que se preze, responde a certas incógnitas do passado e abre novos problemas e caminhos a serem trilhados.

\author{
Wendell Evangelista Soares Lopes \\ Departamento de Filosofia, \\ Universidade Federal de Mato Grosso, Brasil. \\ wendelleslopes@hotmail.com
}

\title{
Gilbert Simondon and a biological philosophy of technology
}

\begin{abstract}
The present article aims to show the meaning of the biological philosophy of technique in Gilbert Simondon. This concept puts into action a reading of the French philosopher's philosophy of technique as a regional ontology within his ontogenetic general ontology, which in that particular scheme is based on an organic model. We will elaborate this to show that the individuation of technical objects, their concretization marked by their functional overdetermination, forces us to think of them in its organicity and from a general organology. Moreover, the concepts of adaptation and associated environment also contribute as biological aspects that accompany Simondon's conception of the mode of existence of technical beings. As a result, we will see that the more concrete and adapted the technical object is - in the series of its specific evolution - the more it comes closer to the proper biological individuality. This approximation will not have, however, the meaning of a complete assimilation between the technical (especially the machinical) and the organic. In the vital self-production, Simondon demonstrates that there always remains something beyond the machinical, namely, the idea of an absolute vital source of technical objects as a "guided mutation". We will show that such a source is not merely human, but also extends to other spheres of the vital domain.
\end{abstract}

KEYWORDS $\bullet$ Simondon. Living beings. Technical objects. Machines. Philosophy of technique. 


\section{REFERÊNGIAS BIBLIOGRÁFIGAS}

Амвrose, S. H. Paleolithic technology and human evolution. Science, 291, 5509, p. 174.8-53, 2001.

Araújo, H. R. (Org.). Tecnociência e cultura: ensaios sobre o tempo presente. São Paulo: Estação Liberdade, 1998.

Barthélémy, J. H. Penser l’individuation. Simondon et la philosophie de la nature. Paris: Harmattan, 2005.

Butler, S. Darwin among the machines. In: Streatfeild, R. A. (Ed.). A first year in Canterbury settlement with other early essays. London: Fifield, 1914. p. 179-86.

Canguilhem, G. Machine et organisme. In:___. La connaissance de la vie. Paris: Librarie Hachette, 1952. p. $124,-59$.

Снавот, P. (Ed.). Simondon. Paris: Vrin, 2002.

Corballis, M. The gestural origins of language. American Scientist, 87, p. 138-45, 1999.

Deleuze, G. \& Guattari, F. O anti-Édipo: capitalismo e esquizofrenia. Rio de Janeiro: Imago, 1976 [1972].

Guchet, X. Les sens de l'évolution technique. Paris: Léo Sheer, 2005.

. Evolution technique et objectivité technique chez Leroi-Gourhan et Simondon. Revue Appareil, 2, 2008. Disponível em: $\langle$ http://revues.mshparisnord.org/appar eil/index.php?id=580 $>$. Acesso em: 11 fev. 2008.

Hart, J. Preface. In: Simondon, G. Du mode d'existence des objets techniques. Paris: Aubier, 1989 [1958]. p. I-XIV.

Jonas, H. Laßt uns einen Menschen klonieren: von der Eugenik zur Gentechnologie. In: Technik, Medizin und Ethik. Frankfurt am Main: Suhrkamp, 1987. p. 162-203.

KING, R. D. Rise of the robo scientists machines can devise a hypothesis, carry out experiments to test it and assess results - without human intervention. Scientific American. Jan. 2011. p. $7^{3-}$.

Margulis, L. Planeta simbiótico: un nuevo punto de vista sobre la evolución. Madrid: Debate, 2002 [1998].

MARgulis, L. \& SAGAN, D. Captando genomas: una teoría sobre el origen de las especies. Barcelona: Kairos, 2003.

Mayr, E. Prólogo. In: Margulis, L. \& SAgan, D. Captando genomas: una teoría sobre el origen de las especies. Barcelona: Editorial Kairos, 2003. p. 13-7.

Ruyer, R. L'individualité. Revue de Métaphysique et de Morale, 47, 3, p. 286-3०4, 194 o. . Les limites du progrès humain. Revue de Métaphysique et de Morale, 63, 4, p. 412-27, $195^{8}$. . A cibernética e a origem da informação. Rio de Janeiro: Paz e Terra, 1972 [1954].

Scheps, R. (Ed.). Oimpério das técnicas. Campinas: Papirus, 1996.

Schmidgen, H. Thinking technological and biological beings: Gilbert Simondon's philosophy of machines. Revista do Departamento de Psicologia - UFF, 17, 2, p. 11-8, 2005.

Simondon, G. Étude critique: les limites du progrès humain. Revue de Métaphysique et de Morale, 64, 3, p. $370-76,1959$.

. L'individu et sa genèse physico-biologique. Paris: PUF, 1964, [1958].

. Du mode d'existence des objets techniques. Paris: Aubier, 1989 [1958].

. Sobre a tecno-estética: carta a Jacques Derrida. In: Araújo, H. R. (Org.). Tecnociência e cultura: ensaios sobre o tempo presente. São Paulo: Estação Liberdade, 1998. p. 253-66.

. L'individuation à la lumière des notions de formes et d'information. Grenoble: Jérôme Millon, 2005a [1958].

. L'invention dans les techniques. Paris: Seuil, 2005b. (Cours et conférences).

. Mentalité technique. Revue Philosophique de la France et de L'etranger, 131, 3, p. 34,3-57, 2006 [1958].

. Entretien sur la mecanologie. Revue de Synthèse, 13o, 1, p. 103-32, 2009 [1968]. 
Stiegler, B. A tecnologia contemporânea: ruptura e continuidades. In: Scheps, R. (Ed.). O império das técnicas. Campinas: Papirus, 1996. p. 169-78.

Streatfeild, R. A. (Ed.). A first year in Canterbury settlement with other early essays. London: Fifield, 1914.

Tibon-Cornillot, M. L’impensé des techniques: les sources involontaires de la démesure technique. In: Снавот, P. (Ed.). Simondon. Paris: Vrin, 2002. p.161-98.

Toscano, A. Tertium datur? Gilbert Simondon's relational ontology. In: The theatre of production: philosophy and individuation between Kant and Deleuze. New York: Palgrave Macmillan. 2006. p. 13656.

Wiener, N. L'homme et la machine. Cahiers de Royaumont. Philosophie, 5, p. 100-5, 1965. Cibernética: ou controle e comunicação no animal e na máquina. São Paulo: Cultrix, 1970.

Algunas consecuencias morales y técnicas de la automación. In: El hombre y las máquinas. Caracas: Monte Avila, 1974. p. 11-23.

VACCARI, A. Vida, técnica y naturaleza en el pensamiento de Gilbert Simondon. Revista CTS, 5 , 14 , p. $15^{3-}$ $65,2010$.

Wolpert, L. Causal belief and the origins of technology. Philosophical Transactions of the Royal Society of London, A, 361, p. 1709-19, 2003. 